Külgazdaság, LXII. évf., 2018. november-december (3-31. o.)

\title{
Hol volt, hol nem volt... Kínai tőkebefektetések Magyarországon és Kelet-Közép-Európában
}

„Félek a görögöktől, még ha ajándékot hoznak is.”

(Vergilius: Aeneis)

\section{SASS MAGDOLNA}

A cikk a szakirodalom eredményei alapján bemutatja, hogy a kinai külföldi közvetlentöke-befektetések és multinacionális vállalatok sajátosan viselkednek más országok külföldön befektetö vállalataihoz képest. Ennek okát a kínai gazdasági modell sajátosságaival magyarázhatjuk, amelyben az állami-kormányzati beavatkozás a gazdaság minden szeletét áthatja. Jelezzük továbbá, hogy a kinai közvetlentöke-befektetések volumene és súlya nagyobb Európában és Kelet-Közép-Európában, mint azt az eddig elérhetö adatok mutatták. A régió s azon belül is elsösorban Magyarország relative fontos célpont az Európai Unión belül a kínai tőke számára. Lakosságszámához vagy gazdasági erejéhez (GDP-jéhez) viszonyítva hazánk a kinai töke fontos európai fogadó országai közé tartozik. A magyarországi kínai projektek jellemzöi hasonlitanak a kinai külföldi közvetlentöke-befektetéseknek a szakirodalomban bemutatott általános sajátosságaihoz. Ezért-más fogadó országok tapasztalatai alapján - a fejlett országokból származó befektetésekhez hasonlítva kockázatosabbnak tekinthetök. ${ }^{*}$

Journal of Economic Literature (JEL) kód: F21, F23.

Kína világgazdasági szerepének növekedésével nemcsak a világkereskedelemben, hanem a világ közvetlentőke-áramlásában is egyre fontosabb szerepet játszik.

* A kutatást az OTKA/NKFIH (109294) támogatta. A cikk a European Trade Union Institute éves konferenciáján (Brüsszel, 2018. június 27-29.) elhangzott előadás kibővített és szerkesztett változata. A szerző köszönettel tartozik a cikk egy elöző változatához füzött megjegyzéseiért, tanácsaiért Antalóczy Katalinnak és az anonim lektornak.

https://doi.org/10.47630/KULG.2018.62.11-12.3

Sass Magdolna, tudományos főmunkatárs, MTA KRTK KTI.

E-mail: sass.magdolna@krtk.mta.hu 
Míg a kilencvenes években elsősorban a Kínába irányuló befektetések voltak jelentősek, addig 2002 óta gyors ütemben nőnek a Kínából eredő, kínai multinacionális vállalatok által külföldön megvalósított közvetlentőke-befektetések (UNCTAD, 2018). A célkontinensek között Európa is fontos, bár nem elsődleges. Seaman et al. [2017] bemutatja, hogyan nőttek a kínai közvetlentőke-befektetések (foreign direct investment - FDI) Európában az utóbbi években, és mennyire fontossá váltak az Európa és Kína közötti kapcsolatok alakulása szempontjából. Döntő változás, hogy a Kínából érkező közvetlentőke-befektetések nagysága először 2016-ban haladta meg az odairányuló európai befektetésekét.

A kínai közvetlentőke-befektetések jelentősen nőttek a kétezres években a kelet-közép-európai országokban, köztük hazánkban is. Sok elemzés foglalkozott már eddig is ezekkel a befektetésekkel, és kiemelték ezek növekedését, politikai meghatározottságát és piackereső motivációit a térségben. Jelen elemzés annyiban lép túl az eddigieken, hogy egyrészt a végső befektető országok szerinti új közvetlentőke-befektetés-adatokon keresztül pontosabb képet ad a kínai befektetők térségbeli részesedéseirôl, ${ }^{1}$ másrészt vállalati szintű adatok alapján vizsgálja néhány jellemzőjüket és összehasonlítja ezeket a kínai külföldi közvetlentőke-befektetések általános jellemzőivel.

A cikk célja, hogy megmutassa, mekkora valójában nemzetközi összehasonlításban a kínai befektetők részesedése Kelet-Közép-Európa országaiban, köztük Magyarországon. Emellett a rendelkezésre álló adatok alapján igyekszik megvizsgálni ezeknek a befektetéseknek a sajátosságait. Ennek megfelelően elsősorban leíró jellegű elemzést tartalmaz.

\section{A kínai közvetlentőke-befektetések nagysága}

Kína néhány év alatt vált jelentős külföldi közvetlentőke-befektetővé: 2001-ben még a globális külföldre irányuló közvetlentőkebefektetés-állomány (outward foreign direct investment - OFDI) kevesebb mint fél százaléka volt kínai eredetü, ez az arány 2017-re csaknem 5 százalékra nőtt (Hongkong nélkül). A 2010-es évek második felében már volt olyan év (2015 és 2016), amikor Kína nettó tőkeexportőr volt, és 2013-tól a kiáramló FDI minden évben meghaladta a 100 milliárd USD-t

${ }^{1}$ Ugyan már több hazai szerző jelezte, hogy az MNB által közölt adatoknál magasabb a magyarországi kínai közvetlentőke-befektetések nagysága, azonban csak a cikk további részében bemutatott új, végső befektető szerinti adatok számszerüsítik ezt megbízható és nemzetközi összehasonlításban is használható módon. 
Hol volt, hol nem volt... Kínai tőkebefektetések Magyarországon...

(UNCTAD, 2018 adatai alapján). Ez a gyors váltás mindenképpen indokolja, miért érdemes a külföldön megvalósított kínai befektetésekkel foglalkoznunk.

Ugyanakkor a kínai befektetések nagyságáról és így a teljes befektetésállományból való részesedéséről sem európai szinten, sem országonként nincsen valós képünk, ami az adatproblémákkal magyarázható (lásd például: Artner, 2010, Matura, 2012, Hanemann-Huotari, 2017). Hanemann-Huotari [2017] kiemeli, hogy a közvetlentőkebefektetésen felül más konstrukciókkal2 is érkeznek kínai beruházók Európába, amelyekkel ellenőrzést, tulajdont vagy jelentős befolyást szerezhetnek különféle európai vállalatokban (Magyarország esetében lásd például: Szunomár et al., 2014). Ezek közül ma már a közvetlentőke-befektetések a legfontosabbak (Fábián et al., 2014), azonban nem hanyagolható el a többi forma sem. A közvetlentőke-befektetések esetében pedig több tényező is torzító hatású (például adóoptimalizálás, régiós központ kijelölése), amelyek az eddig elérhetö, az IMF fizetésimérleg-kézikönyv 5. változata - Balance of Payment Manual, BPM 5 - (IMF, 2003) alapján összeállított adatokat problémássá teszik (Antalóczy-Sass, 2014). Ugyanakkor a különféle, egymásnak sokszor ellentmondó adatokat közlő források (nemzeti bankok, Eurostat, MOFCOM) egyben megegyeznek: mindegyik a kínai közvetlentőke-befektetések dinamikus növekedését jelzi Európában. Az adatproblémák miatt több szerzö (Hanemann-Huotari, 2017) is kiemeli a vállalati adatok fontosságát az elemzésekben. Magyarország esetében is hangsúlyozzák az eddig megjelent cikkek és tanulmányok a vállalati adatok fontosságát. Ez alapján jelezték, hogy a statisztikákban közöltnél hazánkban is jóval magasabb lehet a kínai befektetök valós jelenléte (Szunomár, 2013, Matura, 2011, 2017).

Az eddigi elemzések szerint ugyanakkor a kimutatottnál vélhetően magasabb kínai közvetlentőke-befektetések nem teszik régiónkat a kínai tőke fontos európai célpontjává. Hanemann-Huotari [2017] elemzése szerint a kínai tőke legfontosabb európai célpontjai Nagy-Britannia, Németország, Olaszország, Franciaország és Finnország - ez az öt ország fogadhatja a teljes állomány csaknem négyötödét. $M a$ tura [2011] arra hívja fel a figyelmet, hogy az EU és Kína közötti külkereskedelemben is jóval magasabb a nagy EU-országok, különösen Németország súlya. Jacoby [2014] szerint is Kína szempontjából - a régióbeli és magyar erőfeszítések ellenére is - változatlanul másodlagos Európában a kelet-közép-európai régió és azon belül hazánk szerepe. A későbbiekben új adatok alapján részletesebben is megvizsgáljuk ezt a kérdést.

${ }^{2}$ Elsősorban a kínai hitelből finanszírozott, kínai részvétellel megvalósított nagy infrastrukturális projektek emelhetők itt ki, amelyek főleg a fejlődő országokban valósulnak meg. Lásd például: Marbler-Shan [2017]. 


\section{Kínai multinacionális vállalatok - olyanok, mint a többi?}

A szakirodalomban az egyik legfontosabb kérdés, hogy a fejlett országok „hagyományos" multinacionális vállalataihoz képest mennyiben mások a feltörekvő országok később induló multinacionális vállalatai, és az utóbbi csoporton belül találunk-e olyan specifikus jegyeket, amelyek a kínai multinacionális vállalatok sajátjai. A Magyarországon megvalósított kínai közvetlentőke-befektetések vizsgálatában ez a kérdés úgy merül fel, hogy a kínai FDI ugyanúgy viselkedik-e, mint a fejlett piacgazdaságokból érkező társai, nem jelennek-e meg többletkockázatok a kínai közvetlentőke-befektetésekkel kapcsolatban? A szakirodalom alapján a kínai befektetések néhány fontos tulajdonságát tekintjük át és magyarázzuk a továbbiakban.

A kínai multinacionális vállalatok egyik fontos sajátossága, hogy 2003-ig mindegyikük, azóta pedig túlnyomó részük állami tulajdonban van (Bruton et al., 2015, Buckley et al., 2018). Valójában az egész kínai gazdaságot inkább az állam, mint a piac fogja egybe. Az állami tulajdonlás és a gazdaságban a kiemelkedően magas állami szerepvállalás egyik fontos következménye, hogy a kínai multik külföldi terjeszkedése nemcsak gazdasági, hanem politikai célokat is szolgál. A jelentős kormányzati szerepvállalás és beavatkozás erőteljesen változtatja meg a kínai (potenciális) multinacionális vállalatok tulajdonosi előnyeit ${ }^{3}$ is. Azt mondhatjuk, hogy a kínai kormányzat az országban a források meghatározó „ellenőre” és elosztója, mely szerepeket hủen tükrözik a kormányzati dokumentumok (He et al., 2016). A tulajdonlás és ellenőrzés révén az állam közvetlenül segíti a kínai vállalatokat a különféle erőforrásokhoz való hozzájutásban, különösen a nagyméretủ vállalatok esetében. A méret fontos tényező He et al. [2016] eredményei szerint: pozitívan korrelál az állami segítség nagyságával. Az állami tulajdonú bankok a külső terjeszkedés nagyon kedvező pénzügyi, finanszírozási feltételeit teremtik meg az állami tulajdonú multinacionális vállalatok számára (Carney et al., 2011). ${ }^{4}$ Kormányzati szintủ megegyezések segítik más feltörekvő országokban a helyi természeti erőforrások és a nagy infrastrukturális beruházások kínai befektetők számára való megszerzését. A külföldi befektetőknek az országba vonzása és a kínai vállalatok felé megvalósított

\footnotetext{
3 Tulajdonosi előnyök: ownership advantages, a Dunning [1993] által kidolgozott, a külföldi közvetlentőke-beruházások létét magyarázó elemzési keret, az ún. OLI-paradigma egyik eleme, ahol $O$ a tulajdonosi előnyöket, $L$ a lokalizációs előnyöket, $I$ az internalizációs előnyöket jelöli. Akkor jön létre külföldi közvetlentőke-befektetés, ha ezek az előnyök mind jelen vannak.

${ }^{4}$ Egyes vélemények szerint a pénzügyi forrásokhoz való hozzájutásban korlátozott magáncégeknél egyfajta „nyomó” tényező a nemzetköziesedésben az, hogy külföldön ez az akadály kevésbé jelentős számukra. Ugyanakkor a magán- és állami cégek szétválasztása nagyon nehéz, hiszen mindannyian ugyanannak a rendszernek a részeiként müködnek (Buckley et al., 2018).
} 
Hol volt, hol nem volt... Kínai tőkebefektetések Magyarországon...

technológia- és tudástranszfer ösztönzése révén is erösíti a kormányzat a (potenciális) kínai multinacionális vállalatok versenyképességét (He et al., 2016). Ezen felül Kínában a kormányzat a jelentős infrastrukturális beruházások, speciális gazdasági övezetek és ipari parkok létrehozása, a kutatás-fejlesztést ösztönző, az oktatás fejlesztését célzó politika mellett a nemzetközi szervezetekben (különösen a WTO-ban) és a nemzetközi egyezményekben való részvétellel, a kormányzatokkal folytatott bilaterális tárgyalások révén áttételesen is segítette a kínai vállalatok külföldi versenyképességének javítását (Ramamurti-Hillemann, 2017). Már Buckley et al. [2007] jelezte a kínai multinacionális vállalatok vállalatspecifikus előnyeinek sajátosságait és a kínai OFDI-t befolyásoló hazai intézményi tényezők fontosságát. Kafouros-Wang [2015] meghatározó tényezőnek tekinti a kínai kormányzati politikát a kínai gazdaság, vállalatok és növekedés vizsgálatában. Ramamurti-Hillemann [2017] szerint a kínai multik esetében hangsúlyozottan jelen vannak azok a kormányzat által teremtett elönyök, amelyek kiegészítik Kína erőforrásait és a legtöbb esetben javítják a kínai (potenciális) multinacionális vállalatok nemzetközi versenyképességét. Verbeke-Kano [2015] aláhúzza, hogy a kínai multinacionális vállalatoknak sok esetben nincsenek hagyományos értelemben vett, a fejlett országok multinacionális vállalataira jellemző versenyelőnyeik, hanem speciális előnyökkel rendelkeznek. Más tanulmányok szerint is a kínai közvetlentőke-export speciális és fontos meghatározója a küldő ország intézményi háttere és a kínai kormányzat gazdaság- és külpolitikája (Buckley et al., 2018, De Beule et al., 2017, Seaman et al., 2017). Kelet-Közép-Európa esetében McCaleb-Szunomár [2017] mutatja be az intézményi tényezők fontosságát a kínai tőkebefektetéseknél.

A hazai intézményi környezettel van összefüggésben a kínai multinacionális vállalatok azon sajátossága, hogy sokkal nagyobb kockázatokat vállalnak, mint más nemzetiségü multinacionális vállalatok. Buckley et al. [2007] szerint ez összefügg a laza pénzügyi korlátokkal és azzal, hogy a kockázatos befektetési helyszínek kormányzataival a kínai kormányzat általában erős politikai kapcsolatokat épít ki (Amighini et al., 2013), illetve a kínai kormányzat is tereli egyes esetekben ilyen helyek felé a befektetéseket (Buckley et al., 2018). Ez a jelentős állami befolyásolás, az állam és a gazdaságpolitika, az intézményi háttér meghatározó szerepe azután döntő hatással van a külföldi közvetlentőke-befektetések céljára, motivációira, a nemzetköziesedés sebességére, földrajzi terjedelmére és a belépési mód kiválasztására. Nézzük egyenként ezeket a jellemzőket!

A befektetések célja sok esetben nemcsak gazdasági, hanem politikai is. Így például Deng [2004] szerint a kínai multinacionális vállalatok külföldi leányainak négy 
cél közül legalább az egyiket el kell érnie: fejlett technológia megszerzése, hozzájutás nyersanyagokhoz, külföldi valuta szerzése és exportnövelés. A kínai kormányzat aktívan használja a külföldi befektetéseket (politikai) kapcsolatai erősítésében, például Afrikában és Délkelet-Ázsiában. Európában is fontos befolyásolói a kínai tőkebefektetéseknek a kínai kormányzati célkitüzések, elsősorban a technológiakeresés, a piackeresés, a márkanevek felvásárlása területén; illetve egy-egy jelentős infrastrukturális felvásárlás (Piraeus kikötője, a portugál elektromos vezetékhálózat), vagy tervezett infrastrukturális projekt (például a Budapest-Belgrád vasút) esetében (Seaman et al., 2017).

A motivációkat tekintve Buckley et al. [2007] szerint a 2001-ig terjedő időszakban a piackereső és természeti erőforrás-kereső motiváció a domináns, másfélék (például a hatékonyság vagy a stratégiai előnyök keresése) nem voltak jellemzőek. Később több tanulmány is kiemelte ez utóbbi motivációnak, elsősorban a technológia- és tudáskeresés, illetve a márkanevek felvásárlásának növekvő fontosságát (Luo et al., 2010, Seaman et al., 2017, Buckley et al., 2018), és jelzik ennek összefüggését a kínai kormányzati politikával. Ez különösen érzékenyen érinti az európai felvásárlási célpontokat, hiszen a kontinens versenyelőnye éppen technológiai, innovációs kapacitásán alapul.

A kínai vállalatok nemzetköziesedésének sebessége kiemelkedően gyors. A cégek nem fokozatosan, hanem egyes szakaszokat átugorva nemzetköziesednek ( $\mathrm{Cui}$ et al., 2014). Mivel a nemzetköziesedési folyamat csak nemrégiben kezdődött, a kínai multinacionális vállalatok nemzetköziesedésük korai, induló szakaszában vannak, így - más, érett multinacionális vállalatokhoz képest - egyfajta gyermekkorban levő nemzetköziesedett cégnek tekinthetök (Ramamurti-Hillemann, 2017). Ez részben magyarázza is tulajdonosi előnyeik gyengeségét és eltéréseit. Ramamurti [2009] szerint a gyermekkorú multik versenyelőnyei általában is erősebben függnek az anyaország előnyeitől, a cégek tulajdonosi előnyei jobban kötődnek az anyavállalathoz és annak földrajzi helyéhez, mivel még nem tudták a nemzetköziesedésből „megnövelni” ezeket az előnyöket. Így nemzetköziesedettségük foka is (például a TNI ${ }^{5}$ alapján) alacsonyabb, technikai-technológiai előnyük is korlátozottabb, mint fejlett országokból származó versenytársaiké. Ugyanakkor nemzetköziesedésük gyorsasá-

$5 \mathrm{TNI}=$ transznacionalitási index: Az UNCTAD által kidolgozott és alkalmazott mérőszám, amely a vállalat nemzetköziesedettségét méri. Három mutató egyszerủ számtani átlaga: külföldön befektetett eszköz/összes eszköz, külföldi foglalkoztatottak/összes foglalkoztatott és külföldi eladás/ összes értékesítés. 
Hol volt, hol nem volt... Kínai tőkebefektetések Magyarországon...

gát jelzi, hogy 2016-ra öt kínai multinacionális cég TNI-je haladta meg az 50 százalékot (Casanova-Miroux, 2016).

A nemzetköziesedés földrajzi terjedelme is tágabb, mint az a cégek versenyelőnyei és a pszichikai-kulturális távolság jelentette kockázatok és költségek alapján várható lenne (Ramamurti, 2012). Európa és az USA is igen hamar bekerült a kínai cégek terjeszkedési célpontjai közé. A nemzetköziesedés földrajzi célpontjait befolyásolja, hogy mennyire nagy a kulturális különbség, amelynek egyik eleme, hogy van-e kínai kisebbség a célországban (Buckley et al., 2007). Amennyiben van, az növeli a helyi kínai befektetéseket. Kutatási eredmények szerint a kínai multik befektetési helyszíneinek kiválasztásába a kormányzat is beleszól ( $L u$ et al., 2014), és segítheti ezt diplomáciai eszközökkel, a fogadó ország kormányával való megegyezésekkel. Részben ez is magyarázza a távolabbi és kockázatosabb célpontok választását. Másrészt egyes értelmezések szerint ez a kormányzati segítség, a befektetések útjának egyengetése is része lehet a kínai multinacionális vállalatok tulajdonosi előnyének. Ezt a célt szolgálják a különféle nemzetközi kezdeményezések is, például régiónkban a $16+1$ együttmüködés, vagy Afrikában a Kína-Afrika Együttmüködési Fóruma. Ezek révén a kínai kormányzat saját vállalatai számára kedvezőbb helyi környezetet teremt, mint amilyen egyébként elérhető lenne (van Hoorn-Maseland, 2016).

A nagy elkötelezettséggel járó és jelentős forrásokat igénylő belépési módok hamarabb megjelentek a kínai multinacionális vállalatoknál, mint tulajdonosi előnyük, versenyképességük alapján várható lett volna (Deng, 2009). Ebben is fontos szerepe van a kínai államnak: a küldő és fogadó ország intézményei és a kínai vállalatok állami tulajdona, illetve a belépési mód között talált összefüggést Cui-Jiang [2012] és Xie [2017]. A motivációk szerint eltérhetnek a választott belépési módok. Például a stratégiai előnyt kereső vállalatok esetében a felvásárlás dominál (Anderson-Sutherland, 2015). Általában is egyre inkább a felvásárlás fontosabb, míg a zöldmezős beruházások súlya csökkenő (EIU, 2015).

Természetesen a nemzetközi gazdasági és politikai környezet változása is fontos szerepet játszik a kínai cégek gyors nemzetköziesedésében. Ramamurti-Hillemann [2017] kiemeli, hogy alapvetően eltér a megelőző évtizedek nemzetközi környezetétől az, amelyben a kínai vállalatok megkezdték és folytatják gyors nemzetköziesedésüket. Vagyis könnyebb a vállalatok nemzetköziesedése a tőkeáramlás és a külkereskedelem liberalizációja, a regionális integrációk, a globális értékláncok, az információs és más technológiák gyors fejlödése korában. Ramamurti-Hillemann 
[2017] ezt tartja a négy legfontosabb tényező egyikének, amelyik sajátossá teszi a kínai multinacionális vállalatok nemzetköziesedését.

A kínai multinacionális vállalatok további fontos jellemzője, hogy jelentős az iparági koncentrációjuk. Ramamurti-Hillemann [2017] szerint a későbbi indulás egyes kínai cégek számára jelentős előnnyel járt, elsősorban a hanyatló (környezetszennyező) és egyes felemelkedő, high-tech iparágakban. Így a hanyatló ágazatokban a későbbi, a felemelkedő ágazatokban pedig a korai indulásból származó előnyöket használták ki. A hanyatló iparágakban a későbbi indulás miatt rögtön a legfejlettebb technológia, a nagyon rugalmas munkaerőpiac és a skálahatékonyság előnyeit használhatták ki a kínai multik. A felemelkedő iparágakban a kormányzati politika, a régi technológiához nem ragaszkodó (azt nem ismerő) hatalmas belső fogyasztói és vállalati kereslet segített a versenyelőny megteremtésében.

A kínai multinacionális vállalatoknak főleg a belső környezet által meghatározott és a külső környezet által segített nemzetköziesedése teszi sajátossá leányvállalataik viselkedését is. Így a kínai tőkebefektetések speciális jellege miatt magasabbak a kapcsolódó kockázatok a fejlett országokból érkező külföldi közvetlentőkebefektetésekhez képest.

Érdemes megnézni, miben állhat ez a magasabb kockázat. Seaman et al. [2017] elemzése szerint ezek forrása Kínában a kiugróan nagy állami szerepvállalás, a verseny hiánya, az agresszív technológiakeresés és a technológiai vezető szerep célkitűzése. Ehhez járulnak Európában a biztonságpolitikai szempontból fontos infrastruktúrával és érzékeny technológiákkal kapcsolatos kérdések bizonytalan kezelése, a közvetlentőke-befektetések politikai és geopolitikai befolyásszerzésre való felhasználásával kapcsolatos európai feszültségek, illetve az Európán belüli verseny a kínai befektetésekért, a szabályozási problémák és a növekvő „ígéretfáradtság” (megígért, de be nem váltott kínai beruházási ígéretek, tervek). Ezek mind nehezen számszerüsíthető, de valószínüleg jelentős pluszköltségeket jelentenek a kínai tőkebefektetések esetében a fejlett országokból érkezőkhöz képest. Clegg-Voss [2018] szerint kockázatot jelent még, hogy a jelentős állami szerepvállalás és ösztönzés miatt a fejlett országokban piacra lépő kínai multinacionális vállalatok sok esetben nem megfelelően készültek fel a fogadó gazdaságban található éles versenyre. Ha nincs lehetőség állami segítségre, akkor problémáik adódhatnak. Holtbrügge-Bernin [2018] kutatásai is ezt támasztják alá: a sikeres kínai befektetések Európában nagymértékben támaszkodnak a kínai kormány segítségére. Buckley et al., [2018] a kínai multinacionális vállalatoknál a transzparencia hiányából és a felvásárolt vállalatok „,vagyonkimazsolázásából” (asset stripping) fakadó kockázatokra hívják fel 
Hol volt, hol nem volt... Kínai tőkebefektetések Magyarországon...

a figyelmet, a németországi Kuka és Aixtron esetét említve. Jelzik továbbá, hogy a Huawei (fokozatos) vagy a Haier (gyors, ugrásszerü) nemzetköziesedést követö vállalatok alapvetően másként viselkednek és eltérő kockázatokat hordoznak a fogadó gazdaságok számára is. Ezen felül jelentős kockázatokat jelentenek a kevésbé fejlett országok számára a hatalmas infrastrukturális projektek finanszírozási feltételei is. Ezek ugyan nem közvetlentőke-befektetések, de hiteltörlesztési problémák fellépésével azzá válhatnak, mivel ilyenkor kínai tulajdonba kerül a szóban forgó infrastrukturális létesítmény. Például Pakisztánban a Belt and Road kezdeményezés részeként megvalósuló, kínai finanszírozású, 55-60 milliárd USD értékủ hatalmas infrastrukturális projektek adósságcsapdába taszíthatják Pakisztánt, és a vártnál jóval kisebb lehet a fogadó gazdaságra gyakorolt pozitív hatásuk. ${ }^{6}$ Srí Lankán megvalósult az adósságból FDI-ügylet: adósságrendezés miatt a Hanbamtota kikötő 99 évre kínai kézbe került. ${ }^{7}$ Afrikában hasonló esetekkel találkozunk: kínai hitelből kínai vállalatok által épített infrastruktúra kerülhet ideiglenesen vagy véglegesen kínai tulajdonba, mivel a fogadó országok nem tudják a hiteleket törleszteni. ${ }^{8}$

Összességében láthatjuk, hogy a kínai multinacionális vállalatok jelentősen különböznek a fejlett és más feltörekvő országok multinacionális vállalataitól, aminek okát elsősorban a kiemelkedően aktív kormányzati szerepvállalásban, a gazdaság erőteljes állami irányításában és az állami tulajdonlás dominanciájában kereshetjük.

\section{Kínai tőke Magyarországon - eddigi kutatási eredmények}

Viszonylag sok elemzés született az utóbbi években a Magyarországon megvalósított kínai közvetlentőke-befektetésekröl. Az elemzések alapján, bár jelentős a versengés a régióban a kínai befektetésekért (és gazdasági partnerségért) (Hamberger, 2012), változatlanul - valószínüsíthetően - Magyarország rendelkezik a legmagasabb befektetett tőkeállománnyal (Hamberger, 2012, Szunomár, 2013, Matura, 2017). E szerzők szerint ez részben a kiemelkedően magas Borsodchem-befektetésnek (a kínai Wanhua-csoport 2011-ben 1,26 milliárd USD-ért vásárolta fel a magyar vállalatot) köszönhetö, de e tranzakció nélkül is magasabb lenne a magyar adat ( $\mathrm{Szu}$ -

${ }^{6}$ Lásd: https://economictimes.indiatimes.com/news/international/world-news/chinese-investment-risks-pakistan-running-into-debt-trap-husain-haqqani/articleshow/63771700.cms és https:// www.ndtv.com/world-news/chinas-infrastructure-boom-in-pakistan-may-have-fewer-benefits-thanthought-1767764

7 Lásd: https://thediplomat.com/2018/01/does-debt-pay-china-and-the-politics-of-investment-insri-lanka/

${ }^{8}$ Lásd: https://www.bbc.com/news/world-africa-45368092 
nomár, 2013). A HITA adatai szerint több mint 5000 kínai tőkével müködő cég van hazánkban (Szunomár et al., 2014). Gyakorlatilag a kínai vezetés régiós befektetési központként tekint hazánkra. Kína számára ugyanakkor régiónk és Magyarország jelentősége változatlanul másodlagos a tőkeexport szempontjából, annak fó célpontjai a többi, elsősorban ázsiai, továbbá afrikai, latin-amerikai fejlődő ország (Szunomár, 2013), illetve a technológia, a know-how és a stratégiai szövetségek kötésével a fejlett országok (Matura, 2011). Matura [2017] hangsúlyozza a magyar kormányzati várakozások és a hazai, Kínából származó közvetlentőke-állomány valódi nagysága közötti diszkrepanciát, és kiemeli a politikai tényezők fontosságát és dominanciáját a gazdasági érdekekkel szemben.

A régiós vezető szerep nem véletlen. Magyarország - európai és régiós versenytársaihoz képest is - több előnnyel rendelkezik a kínai közvetlentőke-befektetések fogadása szempontjából. Artner [2009] szerint ennek fontos elemei a Bank of China jelenléte, a jelentős kínai diaszpóra és a kínai-magyar két tannyelvü iskola jelenléte, a kedvező földrajzi fekvés és a magyar oldal gazdaságdiplomáciai erőfeszítései. Ehhez adódik a kínai kereskedelmi központ (China Brand Trade Center) megnyitása (Artner, 2010). Szunomár [2013] a földrajzi fekvés, a geopolitikai helyzet fontosságát emeli ki kínai szempontból: Magyarország fontos európai közúti és vasúti útvonalak csomópontjában fekszik, így mind a kelet-, mind a nyugat-európai piacok felé kedvező közlekedési és szállítási lehetőségeket kínál. Ez a versenyelőnyünk ugyan közös a régió többi országával, azonban kínai szempontból Szunomár [2013] szerint magyar előny a sikeres és magas szintű világgazdasági integrálódás, a közvetlentőke-befektetések felé való általános nyitottság és azok kedvezőbb hasznosulása, továbbá a kínaiak szemében jelentős az a fejlettségbeli előny, amely az innovációs potenciálban és a külföldi tulajdonban lévő cégek vállalati hatékonyságában nyilvánul meg. Ugyanakkor infrastrukturális problémák (például a Duna magyarországi szakaszának rossz hajózhatósága, a vasútvonalak állapota) akadályozzák ennek a helyzeti előnynek a kiaknázását (Matura, 2011).

A kínai közvetlentőke-befektetések motivációit illetően Szunomár et al. [2018] hangsúlyozza, hogy a régióban befektető kínai vállalatok elsősorban piacokat és hiányzó eszközöket, versenyelönyöket (technikai-technológiai tudást, piaci kapcsolatokat, esetleg márkaneveket) keresnek. Piackereső motivációjuk domináns, és itt a teljes EU-piac is fontos vonzó tényező: sok esetben a kelet-közép-európai régióban végrehajtott beruházások célja a helyi, olcsó összeszerelés alapján a fejlettebb EUországok „ellátása”. Másodlagos motivációként szerepel még a stratégiai előnyök keresése (elsősorban tudás, technológia) is (McCaleb-Szunomár, 2017). 
Hol volt, hol nem volt... Kínai tőkebefektetések Magyarországon...

\section{Kína mint tőkebefektető szerepe a kelet-közép-európai régióban és azon belül Magyarországon. Mit mutatnak az adatok?}

A külföldi közvetlentőke-befektetésekről a legfontosabb adatforrás a fizetési mérlegben található FDI-adat. Az IMF és az OECD által meghatározott FDI-definíció ${ }^{9}$ és statisztikai számbavételi módszerek alapján készülnek az egyes nemzeti bankoknál (ritkábban minisztériumoknál vagy statisztikai hivataloknál) a kifelé és befelé irányuló, folyó (flow) és állományi (stock), negyedéves és éves FDI-adatok. Természetesen ezek az adatok nem teljesen felelnek meg az FDI elméleti meghatározásainak (Antalóczy-Sass, 2014), de az elérhető számbavételi módszerek, pénzügyi források által meghatározott feltételek között igyekeznek összeállítani az adatgyüjtésért felelős szervezetek az IMF és az OECD által meghatározott elöírásoknak megfelelö, nemzetközileg is összehasonlítható adatokat. Az FDI-adat a fizetési mérleg része, ennek megfelelően a rezidens-nem rezidens megkülönböztetés meghatározó: vagyis mind a beáramló, mind a kifelé irányuló FDI-nál az számít, hogy rezidens és nem rezidens közötti tranzakcióról van-e szó. Témánk szempontjából ez azért is érdekes, mert a Magyarországon lakó (rezidens) kínai magánszemélyek hazai vállalkozásai így nem számítanak kínai befektetésnek.

Fontos újdonság az FDI-adatok változása az új fizetésimérleg-kézikönyv (BPM6) $)^{10}$ előírásai szerint (IMF, 2009). Ennek részeként az OECD a végső befektető országok szerinti bontást is kéri a tagországoktól, amelyet azok önkéntes alapon jelentenek. 2014 előtt a nemzeti bankok a fizetésimérleg-statisztikákban a közvetlen és nem a végső befektető alapján tartották nyilván a befektető vállalat nemzetiségét (a megelőző fizetésimérleg-kézikönyv, a BPM5 elöírásai alapján). Történetileg a multinacionális vállalatok térnyerésének folyamatában sokáig a közvetlen és a végső befektető anyaországa ${ }^{11}$ az esetek többségében ugyanaz volt. A kilencvenes évektől kezdve azonban egyre több esetben jelentek meg közvetítő ország révén harmadik országokban a multinacionális vállalatok. Ennek oka többféle lehet: a „közvetítő” ország jobban ismeri a végső befektetési célpontot, ott kapcsolatokkal, piacismerettel rendelkezik, más esetben a befektető vállalat el akarta rejteni eredeti származását

\footnotetext{
9 Az IMF szerint a közvetlen külföldi befektetés olyan nemzetközi befektetés, amelynek révén az egyik országban székhellyel rendelkező (rezidens) vállalat vagy magánszemély egy másik országban mủködő vállalatban tartós érdekeltséget szerez, és a befektető és fogadó vállalat között hosszú távú viszonyt hoz létre, amely meghatározó mértékben befolyásolja a vállalat stratégiáját, menedzselését. A meghatározó mérték 10 százalék vagy a fölötti részvénytulajdon (IMF, 2003).

${ }^{10}$ Lásd: https://www.imf.org/external/pubs/ft/bop/2007/bopman6.htm

${ }^{11}$ Amelyik országban rezidens a befektető vállalat.
} 
(Kalotay, 2012). (Például néhány feltörekvő, így kínai multinacionális vállalatnál találunk erre példát, amelyek - sokszor joggal - gondolhatják, hogy a fogadó országban nem övezné egyöntetü lelkesedés a kínai befektető megjelenését, netán az általa megvalósított vállalatfelvásárlást.) Legtöbbször adózási okok játszanak szerepet: érdemes valamelyik kedvező szabályozású országbeli leányvállalatot beiktatni a befektetési láncba. ${ }^{12}$ Ennek megfelelően a közvetlen befektetők szerinti országbontás sok esetben jelentősen eltért a végső befektetők szerinti országszerkezettől egy-egy fogadó ország esetében. Magyarországon is ez a helyzet. Az MNB 2014-re vonatkozó adatai és elemzése (MNB, 2016, Montvai, 2016) szerint jelentősen eltér a befektető országok sorrendje a közvetlen és a végső befektetők szerint. Nézzük meg például, hogy néhány magyarországi kínai befektetés esetén hogyan alakul a közvetlen és a végső befektető nemzetisége! (Lásd az 1. táblázatot.)

A közvetlen befektető nemzetisége egyes magyarországi, kínai (végső) tulajdonban levő vállalatok esetén

\begin{tabular}{|c|c|c|c|}
\hline $\begin{array}{l}\text { A magyarországi leány- } \\
\text { vállalat neve }\end{array}$ & Az anyavállalat & $\begin{array}{l}\text { A végső } \\
\text { befektető } \\
\text { nemzeti- } \\
\text { sége }\end{array}$ & $\begin{array}{l}\text { A közvetlen befektető nemzeti- } \\
\text { sége }\end{array}$ \\
\hline $\begin{array}{l}\text { Huawei Technologies } \\
\text { Hungary }\end{array}$ & $\begin{array}{l}\text { Huawei Technologies } \\
\text { Investment Co. Limited } \\
\text { and Skycom Tech. Co. } \\
\text { Limited }\end{array}$ & kínai & holland (100\%) \\
\hline Yanfeng & $\begin{array}{l}\text { Shanghai Automotive } \\
\text { Industry Corp. }\end{array}$ & kínai & brit $(100 \%)$ \\
\hline ZTE Hungary & ZTE (Zhongxing) & kínai & holland (100\%) \\
\hline Borsodchem & Wanhua & kínai & $\begin{array}{l}\text { magyar }(100 \%) \text {, köztes: luxem- } \\
\text { burgi }(96 \%) \text {, ciprusi }(4 \%)\end{array}$ \\
\hline $\begin{array}{l}\text { BYD Electric Bus and } \\
\text { Truck Hungary }\end{array}$ & $\begin{array}{l}\text { BYD (H.K.) Co., LIMI- } \\
\text { TED }\end{array}$ & kínai & hongkongi (100\%) \\
\hline
\end{tabular}

Forrás: Saját összeállítás az érintett vállalatok mérlegbeszámolóinak kiegészítő melléklete alapján.

12 Lásd például az ún. Dutch sandwichről és az ún. Double Irishról: Antalóczy-Sass [2014]. 
Hol volt, hol nem volt... Kínai tőkebefektetések Magyarországon...

1. ábra

\section{A három visegrádi ország összesített FDI-állománya közvetlen és végső befektető szerint, 2016}

(Millió USD)

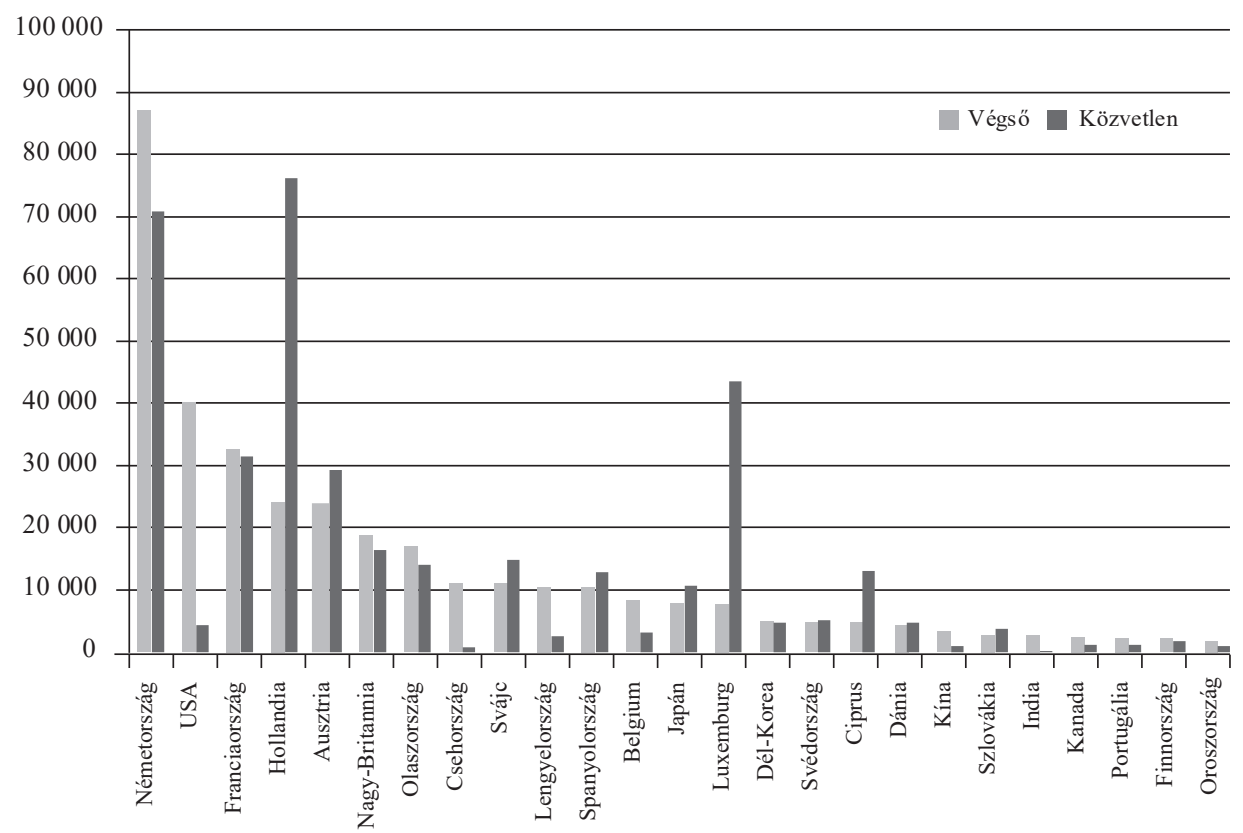

Forrás: OECD FDI position by partner country BMD4 (https://stats.oecd.org/Index. aspx?DataSetCode=FDI_POS_CTRY) és Magyar Nemzeti Bank (http://www.mnb.hu/statisztika/ statisztikai-adatok-informaciok/adatok-idosorok/viii-fizetesi-merleg-kozvetlen-tokebefektetesek-kulfolddel-szembeni-allomanyok/kozvetlentoke-befektetesek/bpm6-modszertan-szerinti-adatok).

Sok külföldi tulajdonban levő vállalat esetében találunk példát arra, hogy a befektető multinacionális cég valamelyik harmadik országbeli leányvállalatán keresztül valósítja meg a magyarországi befektetést. Az 1. táblázat alapján is látható, hogy sok kínai befektetés egy másik közvetítő országon keresztül érkezik Magyarországra, így eddig nem kínai eredetüként szerepelt a közvetlen befektető nemzetisége alapján összeállított statisztikákban. Egyes esetekben egy több elemből álló tulajdonosi lánc végén található a befektetést valóban ellenőrző kínai tulajdonos, mint például a Borsodchem esetében. Az új, végső befektető szerinti statisztikák azonban már Kínához rendelik ezeket a befektetéseket is. Így az új adatsorok alapján pontosabb képünk lehet az itt lévő kínai tőke nagyságáról. (Azért akadnak itt is prob- 
lémák: egyelőre csak néhány ország nemzeti bankja birkózott meg azzal a hatalmas feladattal, hogy megkeresse a végső befektetőket, és így jelezze, valójában honnan jön a tőke. Szerencsére a régiónkból Csehország, Lengyelország és Magyarország esetében is rendelkezésre állnak az adatok. Ugyanakkor az EU-15 nagyobb országainak többsége még csak az előzetes számokat publikálja. Így az országonkénti összevetés mellett a tükörstatisztikák használata lehetőségének hiánya is nehezíti a nemzetközi összehasonlítást. Egy további probléma lehet, hogy a nehezen vagy nem felderíthető eseteket a közvetlen befektető országához rendelik.)

Először vizsgáljuk meg, hogy Magyarország tágabb régiójában, a visegrádi országokban milyen Kína súlya az FDI-állományban! A végső befektető szerinti FDIadatok Csehország, Magyarország és Lengyelország esetében állnak rendelkezésre (lásd az 1. ábrát).

A régió három országának összesített FDI-állományát tekintve Kína a tizenkilencedik legnagyobb befektető, és a valós FDI-állomány több mint háromszorosa annak, mint amennyi a közvetlen befektetők adatai alapján volt (947 millió USD a közvetlen és 3416 millió USD a végső befektető nemzetisége alapján). Az adatok azt is jelzik, hogy - bár mindhárom országban magasabb a végső kínai befektetők szerinti állomány, mint a közvetlenül Kínából érkező tőke szerinti - a régióban Magyarország a legfontosabb kínai befektetési célpont. Ugyanakkor még így is elmondható, hogy a kínai tőke részesedése a teljes befektetett FDI-állományból elhanyagolható (1 százalék alatti) Csehország és Lengyelország esetében, és nagyon kicsiny (3 százalék alatti) Magyarország esetében (lásd a 2. táblázatot).

2. táblázat

\section{A kínai FDI nagysága és részesedése a közvetlen és a végső befektetők szerinti} FDI-állományban, 2016

(Millió USD és százalék)

\begin{tabular}{lcccccc}
\hline & \multicolumn{2}{c}{ Csehország } & \multicolumn{2}{c}{ Lengyelország } & \multicolumn{2}{c}{ Magyarország } \\
\cline { 2 - 7 } & Állomány & Részesedés & Állomány & Részesedés & Állomány & Részesedés \\
\hline Közvetlen & 529 & 0,5 & 131 & 0,1 & 287 & 0,3 \\
Végső & 758 & 0,7 & 588 & 0,3 & 2071 & 2,6 \\
\hline
\end{tabular}

Forrás: Lásd az 1. ábránál. 
Hol volt, hol nem volt... Kínai tőkebefektetések Magyarországon...

Érdemes megnézni, hogy más EU-tagországokhoz képest mennyire fontos a vizsgált három ország és azon belül elsősorban Magyarország a kínai tőkebefektetések szempontjából. A már említett adathiányok megnehezítik ezt az összevetést. Mindössze 11 európai országra állnak rendelkezésre a végső befektető szerinti adatok (lásd a 2. ábrát). Itt azoknak az országoknak az adatai szerepelnek, amelyeknél vagy az OECD adatbázisából érhetők el a közvetlen és a végső befektető szerinti adatok is, vagy a saját nemzeti bankjuk honlapján publikálnak előzetes adatokat.

2. ábra

\section{A kínai tőke nagysága a közvetlen és a végső befektető szerint egyes európai országokban, 2016 \\ (Millió USD)}

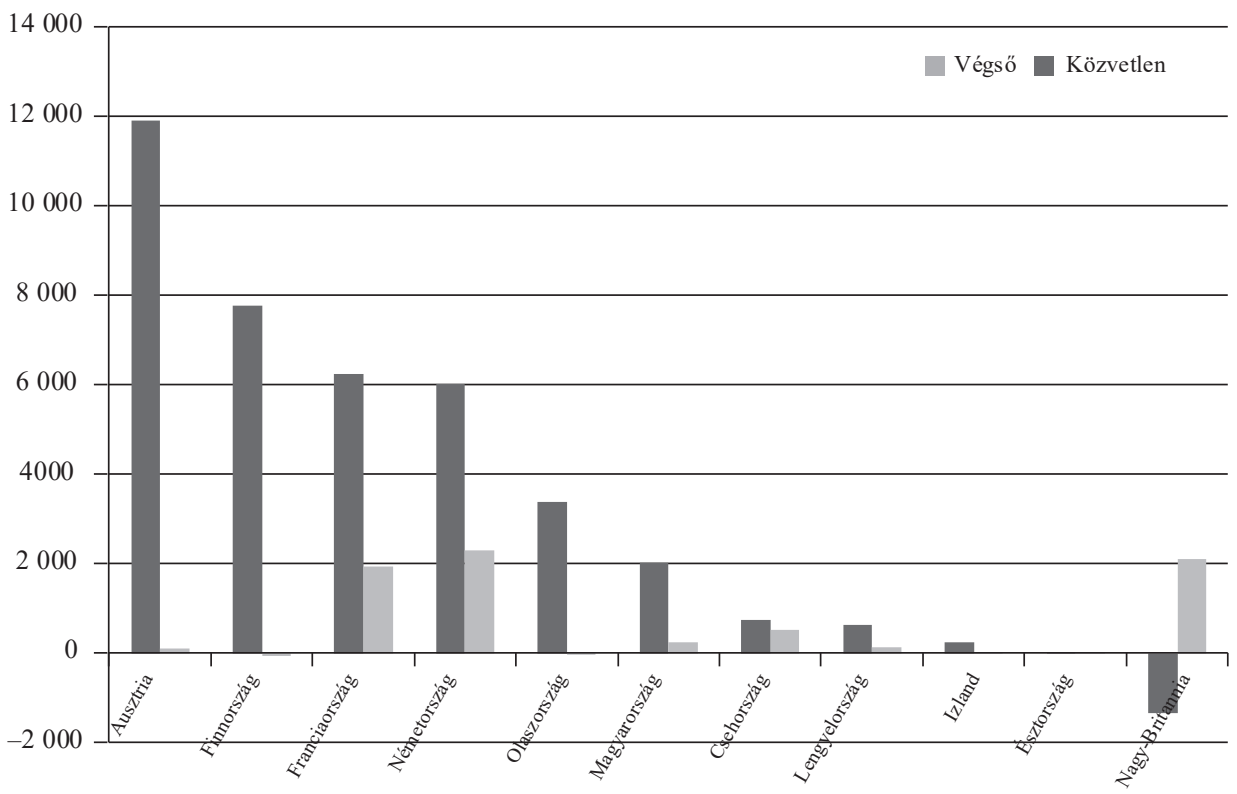

Megjegyzés: Olaszország esetében a Pirellinek a ChemChina által történt megvásárlása, amely egy kiugróan nagy, több tízmilliárd USA dollár értékủ, kínai befektető által megvalósított felvásárlás volt, nem szerepel a 2015-ös adatokban. Lásd: https:/www.ft.com/content/0989f64e-a828-11e7-93c5648314d2c72c Forrás: OECD FDI position by partner country BMD4 (Csehország, Lengyelország, Észtország, Izland, Olaszország) és MNB [2016], Office for National Statistics (https://www.ons.gov. uk/releases/ukforeigndirectinvestmenttrendsandanalysisjuly2018), Bundesbank [2017], Banque de France (https://www.banque-france.fr/sites/default/files/media/2016/11/16/ide_stock_etr_fr_v2017. xlsx, Statistics Finland: becslés az ábra alapján (2016-os adat, éves átlagos árfolyammal átszámítva USD-re. http://www.stat.fi/til/ssij/2016/ssij_2016_2017-11-30_en.pdf). 
Látható, hogy csaknem mindegyik európai ország esetében jelentősen magasabb a tulajdonosi lánc végén kínai kézben levő befektetések állománya, mint a közvetlenül Kínából érkező befektetéseké. Ugyanezt mutatják egyébként az USA adatai is:13 a kínai, közvetlenül Kínából érkező FDI-állomány nagysága 2016-ban 27475 millió USD volt, míg a végső befektető szerinti kínai befektetések állománya csaknem kétszer ekkora, 58154 millió USD. Nagy-Britannia esetében egyrészt a brexit, másrészt az új szabályok - amelyek kötelezővé teszik a felvásárlások és zöldmezős beruházások esetén a végső befektető felfedését (Buckley et al., 2018) - okozhatták 2014-től, hogy évröl évre csökken a végső befektető szerinti kínai FDI-állomány az országban (egyébként a jóval magasabb hongkongi állomány nem csökken, ami tovább árnyalja a képet...). A brit adat ellenére is megkockáztathatjuk, hogy az Európában befektetett kínai össztőkeállomány is jóval magasabb a közvetlen befektető nemzetisége szerinti adatok alapján gondoltnál. Alátámasztja ezt, hogy a tizenegy kiemelt ország együttes, végső befektető szerinti FDI-állománya több mint ötszöröse (37,6 milliárd USD) a közvetlen befektető szerinti kínai FDI-állománynak (7,3 milliárd USD) - még a brit negatív végső befektető szerinti állomány ellenére is. Így az európai kínai FDI-állomány elérheti az 50 milliárd USD-t. ${ }^{14}$

A brit példa felhívja a figyelmet arra, hogy érdemes lehet a Hongkongból érkező befektetéseket is figyelembe venni. A Hongkongból érkező végső befektető szerinti állomány nagyjából kétharmada a Kínából érkezőnek (23,4 milliárd USD versus a már említett 37,6 milliárd USD). A hongkongi befektetések egy részében is feltehető, hogy valójában kínai közvetlentőke-befektetésről van szó. ${ }^{15}$ Nagy-Britannia esetében egyértelmű Hongkong szerepe, persze a közös történelmi múlt is magyarázó tényező. Érdekes még, hogy Franciaországban is jelentős a Hongkongból származó FDI, hasonló nagyságrendü, mint a Kínából érkező. A többi ország esetében nincs jelentős változás (lásd a 3. ábrát.)

A visegrádi országok és köztük Magyarország állományi adatának értékelésében a GDP-hez és lakosságszámhoz viszonyított adatok nyújthatnak támpontot (lásd a 4. ábrát). Ez alapján Ausztria, ${ }^{16}$ Finnország és Izland mellett Magyarország a

\footnotetext{
${ }_{13}$ A hat európai ország mellett még az USA közli a BPM6 szerinti adatokat az OECD adatbázisában.

${ }^{14}$ Hiányzik például Bulgária, Hollandia vagy Svédország adata is, ahol kínai cégek nagyobb vállalatokat vásároltak fel vagy zöldmezős beruházással jelentek meg.

${ }^{15}$ Lásd például: http://www.hktdc.com/ncs/coi/en/main/index.html, amely szerint a kínai OFDI 60 százaléka megy keresztül vagy irányul Hongkongba.

${ }^{16}$ Két jelentős vállalatfelvásárlás magyarázhatja a magas osztrák adatot: A-TEC Industries AG-é és az ATB Groupé. Finnországban a Supercell, az Okmetic, a Rightware (mind high tech-vállalatok)
} 
Hol volt, hol nem volt... Kínai tőkebefektetések Magyarországon...

kínai befektetések szempontjából lakosságszámát, gazdasági erejét (GDP) tekintve fontosabb célpont, mint a vizsgált többi fejlett európai és kelet-közép-európai ország.

3. ábra

\section{Kína és Hongkong mint végső befektető a vizsgált országokban, 2015 vagy 2016}

(FDI-állomány, millió USD)

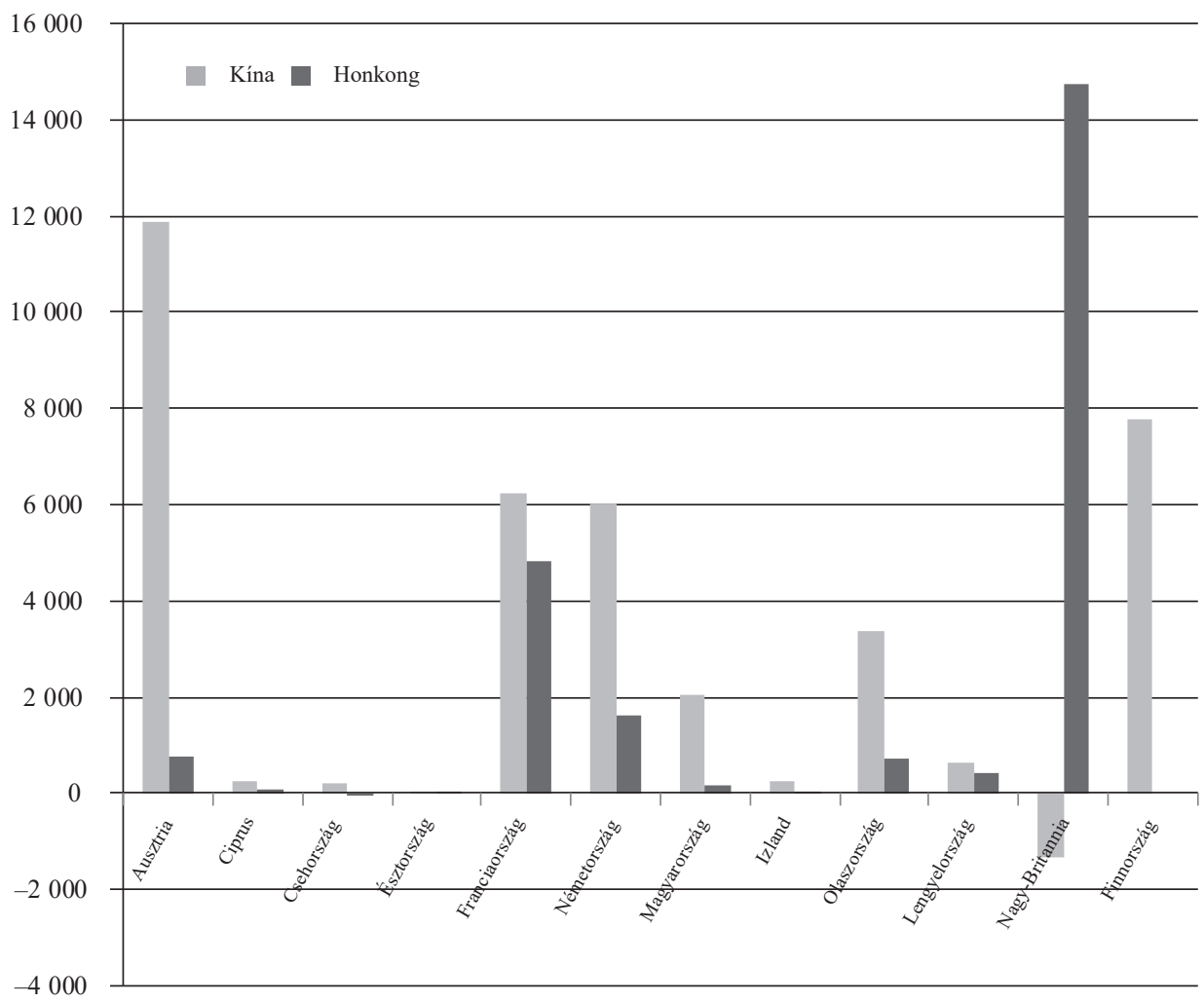

Forrás: Lásd a 2. ábránál.

felvásárlása jelentős. Lásd: https://www.investinfinland.fi/-/why-does-finland-attract-chinese-investment- 
4. ábra

\section{Kínai FDI-állomány (végső befektető szerint) a lakosságszámhoz és a GDP-hez viszonyítva, 2015 vagy 2016}
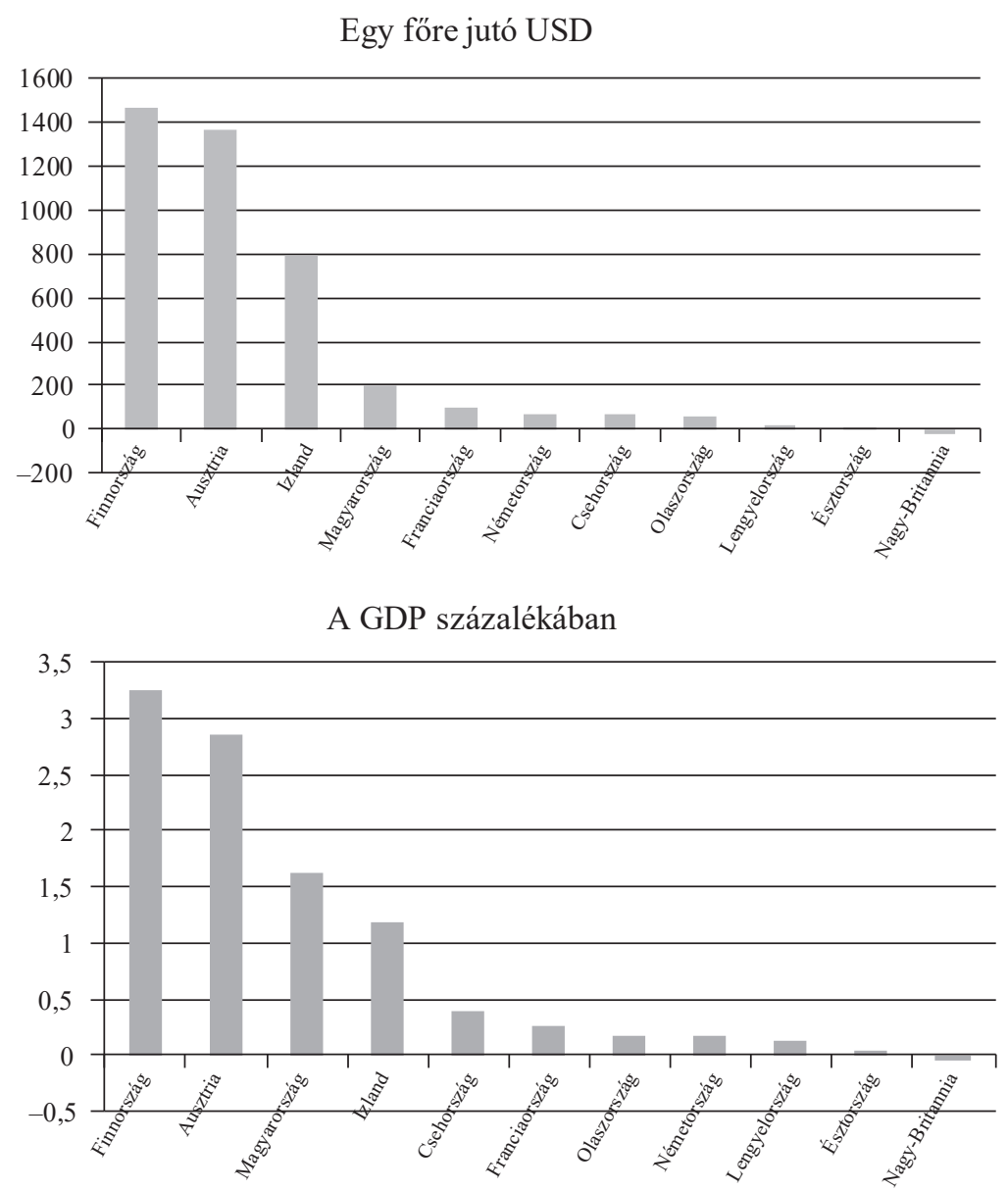

Forrás: Végső befektető szerinti kínai FDI-állomány. FDI: Lásd az 1. ábránál. Lakosságszám forrása: Világbank (lásd: https://data.worldbank.org/indicator/SP.POP.TOTL), a GDP forrása: IMF Data Mapper (lásd: https://www.imf.org/external/datamapper/NGDPD@WEO/OEMDC/ADVEC/WEOWORLD).

A kínai FDI-adatokat a MOFCOM (Ministry of Commerce) közli. Ezeknél is fontos torzító tényező, hogy a közvetlen és nem a végső külföldi befektetési célország szerint csoportosítják az adatokat. Ennek köszönhető, hogy a 2015-ös kife- 
Hol volt, hol nem volt... Kínai tőkebefektetések Magyarországon...

lé irányuló kínai közvetlentőke-befektetés több mint 70 százalékának célországai Hongkong vagy valamelyik karib-tengeri adóparadicsom (Hanemann-Huotari, 2017). Ez utóbbi esetben a tőkemenekítés célja is felmerülhet motivációként, ami további torzítást visz az adatokba. ${ }^{17}$

Magyarország esetében Kína a végső befektetői adatok alapján a 10. legfontosabb befektető ország, bár a befektetett tőke nagysága eltörpül egyes európai országok vagy az USA befektetései mellett (lásd az 5. ábrát).

5. ábra

Magyarország összesített FDI-állománya közvetlen és végső befektetők szerint (Millió USD, 2016)

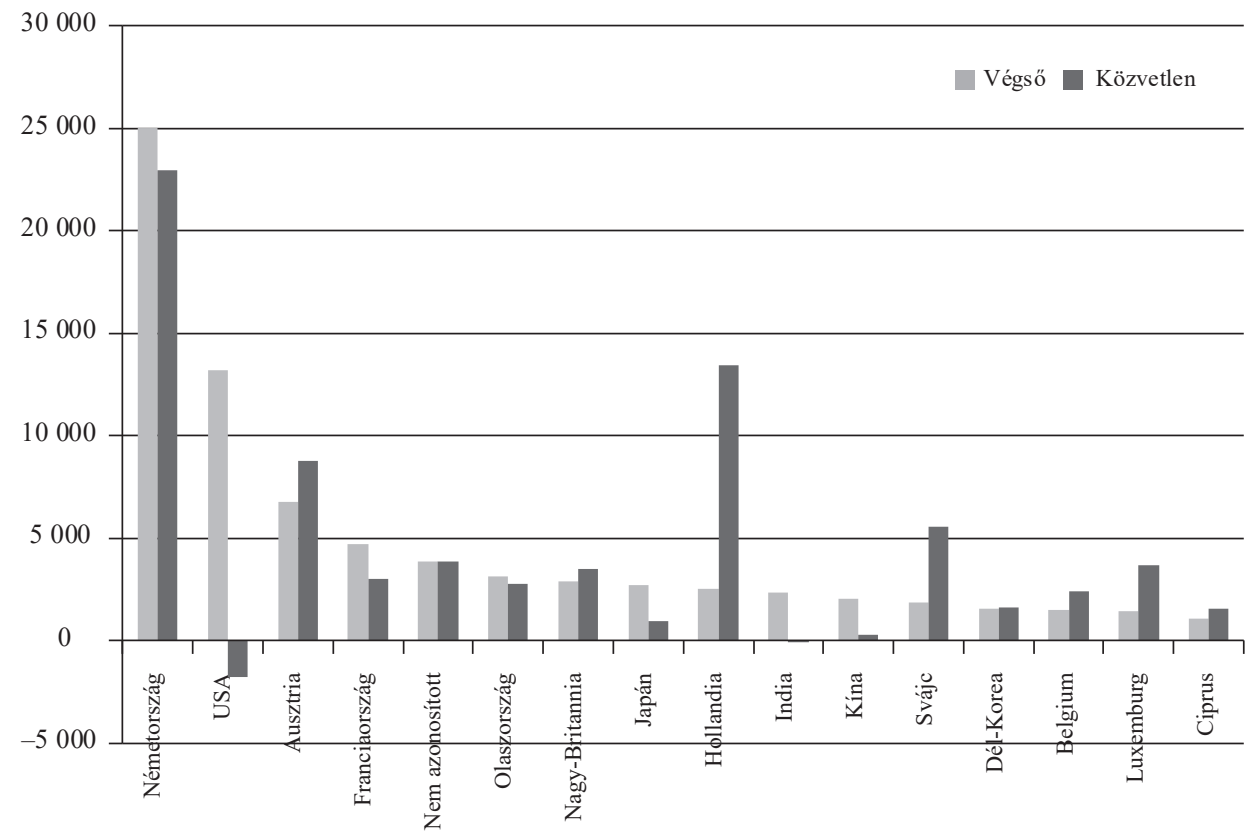

Forrás: Magyar Nemzeti Bank adatai éves átlagos USD-EUR árfolyammal átszámítva.

17 A tőkemenekítés motivációja valószínüsíthető ugyanis a speciális célú vállalatok révén az adóparadicsomokban vagy az ingatlanban megvalósított külföldi tökebefektetéseknél (Buckley et al., 2015). 
A vezető befektető országok: Németország, az USA és a jelentős európai befektető országok (Ausztria, Franciaország, Nagy-Britannia, Olaszország, Hollandia) után Japán és India mellett Kína a vezető ázsiai befektetők közé tartozik hazánkban. Az Európán kívüli befektetők között Kína az USA és Japán után a harmadik. Vagyis a befektetett kínai állomány súlya nagyobb európai összehasonlításban is, mint az eddig elérhető, közvetlen befektető országok szerinti adatok alapján gondoltuk.

\section{Mit mutatnak a vállalati adatok?}

A legfontosabb magyarországi kínai befektetések beazonosítása és a vállalati adatok elemzése alapján lehetővé válik a hazai kínai befektetés-állomány néhány jellemzőjének meghatározása. A Mellékletben található táblázatban 16 magyarországi kínai tulajdonban levő vállalat néhány jellemzőjét gyüjtöttük össze elsősorban az anya- és leányvállalatok honlapjai, mérlegadatai és kiegészítő mellékletei alapján.

A Magyarországon befektető kínai multinacionális vállalatok valóban a legnagyobb kínai cégek közé tartoznak, megtalálhatók a Fortune 2000 vagy a Fortune The World's Largest Public Companies ${ }^{18}$ listáján. Így helytállónak tekinthető $H e$ et al. [2016] állítása, amely szerint leginkább a nagyméretű vállalatok nemzetköziesednek. A befektető vállalatok közül csak a Huawei tekinthető magánvállalatnak - bár a kutatások megkérdőjelezik azt, hogy mennyire müködik a cég állami befolyástól mentesen (Buckley et al., 2018). Így a közvetett kínai állami jelenlét, befolyásolás a magyar leányok esetében is - más fogadó országokhoz hasonlóan - jellemző lehet.

A vállalatok saját tőkéje alapján a magyarországi kínai befektetésállomány több mint 90 százalékát adja a táblázatban szereplö 16 vállalat. A Borsodchem mellett a Yanfeng a másik domináns befektetés ${ }^{19}$ a saját tőke nagyságát tekintve: e két vállalat együtt a teljes befektetésállománynak több mint négyötödét adja. (Egyébként e két vállalat szerepel az 50 legnagyobb saját tőkéjü magyarországi cég 2017-es listáján is. ${ }^{20}$ Vagyis változatlanul jelentős a befektetésállomány koncentrációja, de már nem egyedül a Borsodchem emelkedik ki ebben a tekintetben. A 16 vállalat több mint

${ }^{18}$ Lásd: https://www.forbes.com/global2000/\#582f8f43335d

19 A Yanfeng egy egyesülés révén vált magyarországi befektetővé: az amerikai Johnson Controlsszal való egyesülés révén ment át az USA-beli cég tulajdonában levő magyar gyár 50 százalékban kínai tulajdonba.

20 Lásd: $H V G, 2018$. július 26. 
Hol volt, hol nem volt... Kínai tőkebefektetések Magyarországon...

6000 föt foglalkoztat. Ebből csaknem ötezret a Yanfeng és a Borsodchem - ebben a tekintetben is ennek a két vállalatnak a tevékenysége a meghatározó.

A kínai befektetések ágazati összetételét tekintve Magyarországon viszonylag sok a high-tech iparágakban megvalósított befektetés. A „hanyatló” túlkapacitásokkal rendelkező autóipari ágazat (például Yanfeng) mellett az elektronikai ágazat (Lenovo, Comlink) is jelen van. Ezek mellett a vegyiparnak is jelentős a súlya részben a Borsodchem felvásárlása miatt.

A befektetések motivációiról adhatnak képet a Mellékletben szereplő táblázat adatai, például az exportintenzitás, a föbb (export-) piacok, a tevékenység high-tech volta. A motivációt tekintve vállalati adatok alapján vegyes a kép, leginkább a piackereső motiváció fontos, sok esetben exportplatform ${ }^{21}$ jelleggel, de néha felmerül a hatékonyság- vagy tudáskereső motiváció is. Így például egyértelmű az exportplatform jelleg (Magyarországról az Európai Unióba termel a leányvállalat) a Yanfeng, a Lenovo, a Hisense és kisebb részt a Borsodchem esetében. Ugyanakkor a szolgáltató ágazatban a Bank of China, a ZTE, az Invitel vagy a feldolgozóipari Comlink csak a magyar piacra termel. A hatékonyságkeresés lehet a motiváció azokban az esetekben, amelyekben Hongkongba vagy Kínába viszi vissza a végterméket vagy a köztes terméket a cég, mint például a Beijing Sevenstar (Greensolar) és kisebb részt a Huawei esetében. Ezeknél a vállalatoknál - tevékenységük alapján - a tudáskereső motiváció is jelen lehet. Valamilyen mértékủ tudáskeresést feltételezhetünk még azoknál a leányvállalatoknál, amelyekben jelentősebb K+F-tevékenység folyik, mint például a Huawei, a ZTE, a Neusoft, a Greensolar, a Lenovo, a TCL, a Wanhua és a BYD esetében. Ugyanakkor ezek közül jelentősebb számban szellemi munkaerőt csak a Huawei és a Wanhua alkalmaz.

A belépési módot tekintve hét vállalat vásárolt fel magyar vállalatot, öt (köztük egy alacsonyabb tőkeigényű szolgáltató) zöldmezős beruházással jelent meg. Ez megfelel a kínai multinacionális vállalatok preferált belépési módját elemző kutatások eredményeinek. A vegyes vállalat formájában történő belépés relatíve gyakori: három (és egy kevert) esetben is ezt a belépési módot választotta a kínai beruházó. Ebből az egyik egy nagy léptékü infrastrukturális beruházás, amely még nem müködik. A vegyes vállalati forma általában gyakorinak tekinthető a kínai multinacionális vállalatok esetében, különösen a jelentős infrastrukturális beruházásoknál.

Regionális elhelyezkedésüket tekintve a 16 vállalat közül nyolcnak Budapesten, egynek Budaörsön van a központja, egynek pedig Budapesten is van telephelye.

21 Exportplatform FDI esetében a leányvállalat termelésének meghatározó részét nem a fogadó vagy az anyaországban, hanem harmadik piacokon értékesítik. 
Ezek általában a szolgáltató szektorban müködő vagy induló fázisban levő vállalatok. A termelővállalatok központja általában vidéken található. Ezek közül kettő több telephellyel is rendelkezik, több helyen folytat termelést.

Fontos még megemlíteni, hogy egyes kínai cégek hozzájárulnak a magyarországi (közvetett) tőkeexporthoz is. Néhány kínai anyavállalat magyarországi leányvállalata maga is anyavállalat, mivel külföldi tőkebefektetéseket hajtott végre vagy örökölte azokat.22 Így a Borsodchem esetében a kínai anyavállalat, a Wanhua külföldi leányvállalatokat örökölt, amikor megvásárolta a magyar céget. A vásárláskor még hét külföldi leánya volt a Borsodchemnek, 2016 végén Csehországban, Lengyelországban, Olaszországban, Kínában és Brazíliában rendelkezett leányvállalattal, fióktelepe pedig Brüsszelben, Isztambulban és Zágrábban volt. A Hisense magyarországi gyára franciaországi, belga, olasz- és spanyolországi vállalatokban rendelkezett tulajdoni hányaddal, azonban a magyarországi cég bezárásával ezek a „kifektetések” is megszüntek. Az Invitelnek 2016 végéig egy holland leánya volt. A Beijing Sevenstar/Greensolar magyar leányvállalata 2013-ban vásárolt meg három romániai vállalatot. Itt valószínüleg a magyarországi cég a földrajzi közelség miatt lehet jó kiindulópontja a régióbeli terjeszkedésnek. Hasonló indoka lehet a Bank of China magyarországi leánya regionális terjeszkedésének: 2015-ben a bank fióktelepeket létesített Ausztriában és Csehországban, 2016-ban pedig leányvállalatot alapított Szerbiában, amelynek 100 százalékos tulajdonosa. Láthatjuk, hogy a kínai multinacionális cégek tulajdonosi láncolatai Magyarországon keresztül is húzódnak.

Legvégül pedig fel kell hívnunk a figyelmet arra, hogy a magyarországi kínai befektetések viszonylag békés, botrányok nélküli élete a régióban inkább kivételesnek tekinthető. Lengyelországban a China Oversees Engineering Group (COVEC) ${ }^{23}$ esete (Jacoby, 2014), Csehországban és Szlovákiában a CEFC ${ }^{24}$ esete (Zhu-Tham, 2018) jelzi, hogy viszonylag nagyobb kockázatot hordoznak a kínai projektek.

22 A vállalati mérlegek kiegészítő mellékletei alapján.

23 Az Ázsiában és Afrikában igen aktív COVEC első komoly európai projektje lett volna a lengyel A2-es autópálya megépítése, amelyet közbeszerzésen, nagyon nyomott áron nyert el. Abban bízott, hogy majd újratárgyalhatja - politikai kapcsolatai révén - az árat, illetve majd részben a helyi beszállítókat foglalkoztatja nyomott árakon. Egyik terve sem teljesült, s tetézte a problémákat, hogy nem vette figyelembe a helyi (üzleti) kultúrát. Végül vissza kellett lépnie (Jacoby, 2014).

24 A CEFC-t már csehországi befektetései kezdetén problémásnak tekintették, mivel tulajdonosi szerkezete és pénzügyi forrásainak eredete homályos volt. A vállalat vezetőjének kínai őrizetbe vétele pedig bizonytalanná teszi a cseh és szlovák befektetések jövőjét is (Zhu-Tham, 2018). 
Hol volt, hol nem volt... Kínai tőkebefektetések Magyarországon...

Következtetések

Kína egyre jelentősebb tényezője a világ tőkeáramlásának, már nemcsak a fogadó, hanem a küldő oldalon is. Világgazdasági tapasztalatok szerint politikai tényezők befolyásolják elsősorban a Kínából érkező tőkebefektetéseket. A kínai állam kiemelkedő szerepe mind tulajdonosként, mind a gazdaság szervezésében rányomja a bélyegét a kínai multinacionális vállalatok versenyelőnyeire, viselkedésére, jellemzőire is. Más országok multinacionális vállalatainak közvetlentőke-befektetéseihez képest a kínai projektek jelentős többletkockázatokat hordozhatnak.

A végső befektető szerinti új FDI-adatok szerint Magyarország Európában a kínai töke viszonylag fontos célpontjai között szerepel lakosságszámához vagy gazdasági erejéhez (GDP-je volumenéhez) viszonyítva. A magyarországi kínai nagy projektek erősen koncentráltak: két kiemelkedően nagy befektetés felelős a tőkeállomány és a foglalkoztatottak meghatározó részéért. Ugyanakkor jelen vannak technológiaintenzív beruházások és (jövőbeli sikeres megvalósítás esetén) nagy infrastrukturális projektek is. A magyarországi kínai projektek jellemzői hasonlítanak a kínai külföldi közvetlentőke-befektetéseknek a szakirodalomban bemutatott általános sajátosságaihoz. Ezért a fejlett országokból származó befektetésekhez hasonlítva kockázatosabbnak tekinthetők más fogadó országok tapasztalatai alapján, amit gazdaságpolitikai szempontból fontos figyelembe venni.

A cikk a régióbeli és magyarországi kínai közvetlentőke-befektetéseket vizsgáló tanulmányok sorába illeszkedik, de természetesen rengeteg kérdéssel nem foglalkozik, amelyek további kutatások témái lehetnek. Érdekes lenne megvizsgálni azt a mechanizmust, amellyel a közvetlentőke-befektetések irányíthatók, és közvetlenül politikai célok szolgálatába állíthatók. Érdemes lenne megnézni, hogy a felzárkózás és utolérés szempontjából mennyire lényeges egy-egy országban a saját tulajdonban levő multinacionális vállalatok léte. Fontos lenne elemezni, hogy például Magyarországon eltérően viselkedik-e egy kínai tulajdonú vállalat, mint egy fejlett országbeli multi leánya. Kérdés lehet az is, hogyan értékeljük a kínai közvetlentőke-befektetések sikerességét: a politikai-gazdasági cél (a technológia megszerzése, az exportnövelés, a nyersanyagokhoz való hozzájutás vagy a valutaszerzés) megvalósítása alapján, vagy a megtermelt profit alapján? És természetesen fontos lenne az egyes országok és az Európai Unió szintjén is megvizsgálni, hogy a kínai tőkebefektetések jelentette kihívásra nem lenne-e érdemes egy uniós koordinált választ kidolgozni. Rengeteg a megválaszolásra váró kérdés mind a kínai gazdasággal, mind a külföldi közvetlentőke-befektetésekkel, mind a gazdaságpolitikákkal kapcsolatban. 


\section{Irodalomjegyzék}

Amighini, A. A. - Rabellotti, R. - Sanfilippo, M. [2013]: Do Chinese SOEs and private companies differ in their foreign location strategies? China Economic Review, No. 27., 312-325. o.

Anderson, J. - Sutherland, D. [2015]: Entry mode and emerging market MNEs: an analysis of Chinese greenfield and acquisition FDI in the United States. Research in international business and finance, No. 25., 88-103. o.

Antalóczy Katalin - Sass Magdolna [2014]: Tükör által homályosan: a külföldi közvetlentőkebefektetések statisztikai adatainak tartalmáról. Külgazdaság, 58. évf., 7-8. sz., 30-57. o.

Artner Annamária [2009]: A kínai müködőtőke-kivitel és Kelet-Európa. Közgazdasági Szemle, LVI. évf., 11. sz., 1041-1056. o.

Artner Annamária [2010]: A kínai direkt tőkeexport legújabb fejleményei. Statisztikai Szemle, 88. évf., 9. sz., 931-950. o.

Bruton, G. D. - Peng, M. W. - Ahlstrom, D. - Stan, C. - Xu, K. [2015]: State-owned enterprises around the world as hybrid organisations. The Academy of Management Perspective, Vol. 29., No. 1., 92-114. o.

Buckley, P. J. [2018]: Internalisation Theory and Outward Direct Investment by Emerging Market Multinationals. Management International Review, Vol. 58., No. 2., 195-224. o.

Buckley P. J. - Clegg, J. - Cross A. R. - Liu X. - Voss, H. - Zheng, P. [2007]: The determinants of Chinese outward foreign direct investment. Journal of International Business Studies, Vol. 38., No. 4., 499-518. o.

Buckley, P. J. - Clegg, L. J. - Voss, H. - Cross, A. R. - Liu, X. - Zheng, P. [2018]: A retrospective and agenda for future research on Chinese outward foreign direct investment. Journal of International Business Studies, Vol. 49., No. 1., 4-23. o.

Buckley, P. J. - Sutherland, D. - Voss, H. -El-Gohari, A. [2015]: The economic geography of offshore incorportation in tax havens and offshore financial centres: the case of Chinese MNEs. Journal of Economic Geography, Vol. 14., No. 6., 1-26. o.

Bundesbank [2017]: Foreign direct investment stock statistics. Special Statistical Publication 10, April 2017. Bundesbank, Frankfurt am Main. Letölthetö. https://www.bundesbank.de/Redaktion/ EN/Downloads/Publications/Statistische_Sonderveroeffentlichungen/Statso_10/2017_foreign_ direct_investment_stock_statistics.pdf?_blob=publicationFile

Carney, M. - Gedajlovic, E. R. - Heugens, P. P. - Van Essen, M. - Van Oosterhout, J. H. [2011]: Business group affiliation, performance, context, and strategy: A meta-analysis. Academy of Management Journal, Vol. 54., No. 3., 437-460. o.

Casanova, L. - Miroux, A. [2016]: The emerging multinationals report 2016: The China surge. Cornell University Emerging Markets Institute, Ithaca, NY.

Clegg, L. J. - Voss, H. [2018]: Chinese Outward FDI as a Stimulus to Research in International Business. Management International Review, Vol. 58., No. 1., 1-8. o.

Cui, L. - Meyer, K. E. - Hu, H. W. [2014]: What drives firms' intent to seek strategic assets by foreign direct investment? A study of emerging economy firms. Journal of World Business, Vol. 49., No. 4., 488-501. o.

Cui, L. - Yiang, F. [2012]: State ownership effect on firms' FDI ownership decisions under institutional pressue: A study of Chinese outward-investing firms. Journal of International Business Studies, Vol. 43., No. 3., 264-284. o.

De Beule, F.-Somers, D. - Zhang, H. [2017]: Who follows whom? A location study of Chinese private and state-owned companies in the European Union. Management International Review, Vol. 58., No. 1., 43.-84. o.

Deng, P. [2004]: Outward investment by Chinese MNCs: Motivations and implications. Business Horizons, Vol. 47., No. 3., 8-16. o. 
Deng, $P$. [2009]: Why do Chinese firms tend to acquire strategic assets in international expansion? Journal of World Business, Vol. 44., No. 1., 74-84. o.

Dunning, J. H. [1993]: Multinational enterprises and the global economy. Addison Wesley, Reading, MA.

Fábián Attila - Matura Tamás - Nedelka Erzsébet - Pogátsa Zoltán [2014]: Hungarian-Chinese relations: foreign trade and investments. Current Trends and Perspectives in Development of China-V4 Trade and Investment. Journal of International Relations/Medzinarodne Vztahy. Special Issue, No. 1., 96-106. o.

Godement, F. - Vasselier, A. [2017]: China at the gates: A new power audit of EU-China relations. Letölthetö: http://www.ecfr.eu/publications/summary/china_eu_power_audit7242

Hamberger, Judit [2012]: Kína Közép-Európában. In: Hamberger J. - Matura T. - Szilágyi I.: Kína és Közép-Európa. Magyar Külügyi Intézet. MKI-tanulmányok, No. 27., 5-45. o. Letölthető: http:// www.grotius.hu/doc/pub/FMJVWM/2012_173_hamberger-matura-szilagyi_kina_es_kozepeuropa.pdf

Hanemann, T. - Huotari, M. [2017]: Chinese Direct Investment in Europe: What Available Data Sources Tell Us. In: Chinese Investment in Europe. A Country-Level Approach. ETNC Report, December. French Institute of International Relations (Ifri), Elcano Royal Institute, Mercator Institute for China Studies, 19-29. o.

He, X. - Chakrabarty, S. - Eden, L. [2016]: The global emergence of Chinese multinationals: A resource-based view of ownership and performance. Asian Business \& Management, Vol. 15., No. 1., 1-31. o.

Holtbrügge, D. - Berning, S. C. [2018]: Market entry strategies and performance of Chinese firms in Germany: The moderating effect of home government support. Management International Review, Vol. 58., No. 1., 147-170. o.

IMF [2003]: Foreign Direct Investment Trends and Statistics. October 28. Letölthetö: http://www.imf. org/external/np/sta/fdi/eng/2003/102803.pdf

IMF [2009]: Balance of Payments and International Investment Position Manual. Sixth edition (BPM6). International Monetary Fund, Washington, DC.

Jacoby, W. [2014]: Different cases, different faces: Chinese investment in Central and Eastern Europe. Asia Europe Journal, No. 12., 199-214. o.

Kafouros, M. - Wang, E. Y. [2015]: Technology transfer within China and the role of location choices. International Business Review, Vol. 24., No. 3., 353-366. o.

Kalotay Kálmán [2012]: Indirect FDI. The Journal of World Investment \& Trade, No. 13., 542-555. o.

Kizekova, A. [2018]: China's connections with Europe: Investments beyond the European Union, Culture Mandala. The Bulletin of the Centre for East-West Cultural and Economic Studies, Vol. 12., Issue 2., Article 4., 33-48. o. Letölthetö: http://epublications.bond.edu.au/cm/vol12/iss2/4

Lu, J. - Liu, X. - Wright, M. - Filatotchev, I. [2014]: International experience and FDI location choices of Chinese firms: The moderating effects of home country government support and host country institutions. Journal of International Business Studies, Vol. 45., No. 4., 428-449. o.

Luo, Y. - Xue, Q. - Han, B. [2010]: How emerging market governments promote outward FDI: experience from China. Journal of World Business, Vol. 45., No. 1., 68-79. o.

Majoros Pál [2011]: Kína az új magyar külgazdasági stratégiában. Polgári Szemle, 2. sz. Letölthető: https://polgariszemle.hu/archivum/58-2011-aprilis-7-evfolyam-2-szam/431-kina-az-uj-magyarkulgazdasagi-strategiaban

Marbler, P. - Shan, L. [2017]: Chinese investments in infrastructure worldwide. IRIS, Asia Focus, No. 36., June 2017.

Matura Tamás [2011]: Kína európai befektetései és a magyar kapcsolatok. Magyar Külügyi Intézet. MKI-tanulmányok, 2011-40. Letölthetö: http://kki.hu/assets/upload/Matura.pdf 
Matura Tamás [2012]: Kína gazdasági térnyerése Közép-Európában. In: Hamberger J. - Matura T. Szilágyi I.: Kína és Közép-Európa. Magyar Külügyi Intézet. MKI-tanulmányok, No. 27., 78-89. o. Letölthető: http://www.grotius.hu/doc/pub/FMJVWM/2012_173_hamberger-matura-szilagyi_ kina_es_kozep-europa.pdf,

Matura Tamás [2017]: Chinese investments in Hungary: few results but great expectations. Chinfluence. In: Chinese Investment in Europe. A Country-Level Approach ETNC Report, December 2017. French Institute of International Relations (Ifri), Elcano Royal Institute, Mercator Institute for China Studies, 75-81. o. Letölthető: https://www.ifri.org/sites/default/files/atoms/files/etnc reports_2017_final_20dec2017.pdf

McCaleb, A. - Szunomár, Á. [2017]: Chinese foreign direct investment in Central and Eastern Europe: an institutional perspective. In: Drahokoupil, J. (szerk.): Chinese investment in Europe: corporate strategies and labour relations. Brussels, European Trade Union Institute (ETUI), 2017, 121-140. o.

MNB [2016]: A külföldiek magyarországi közvetlentőke-befektetés állományának végső befektetők szerinti bontása. Letölthető: http://www.mnb.hu/letoltes/a-kozvetlentoke-befektetes-allomanyvegso-befektetore-allokallasa-honlapra.pdf

Montvai, B. [2016]: Towards to interpretable FDI data in external statistics. Filtering distortions arising from globalisation data of multinational enterprises. Paper presented at the Conference of European Statistics Stakeholders, Budapest, 20-21 October.

Ramamurti, R. - Hillemann, J. [2017]: What is „Chinese” about Chinese multinationals? Journal of International Business Studies, Vol. 49., No. 1., 34-48. o.

Ramamurti, R. [2012]: What is really different about emerging market multinationals? Global Strategy Journal, Vol. 2., No. 1., 41-47. o.

Sass Magdolna [2018]: China in Central and Eastern Europe. Panel 17 - The rise of China as a technology superpower - What does this mean for European jobs? Elöadás az ETUI éves konferenciáján. Brüsszel, 2018. június 27-29.

Seaman, J. - Huotari, M. - Otero-Iglesias, M. [2017]: Introduction: Sizing Up Chinese Investments in Europe. In: Chinese Investment in Europe. A Country-Level Approach ETNC Report, December 2017. French Institute of International Relations (Ifri), Elcano Royal Institute, Mercator Institute for China Studies, 75-81. o. Letölthető: https://www.ifri.org/sites/default/files/atoms/files/etnc reports 2017 final_20dec2017.pdf

Szunomár, $\bar{A} .-\overline{M c}$ Caleb, A. - Chen, X. [2018]: Economic Relations between China and Central and Eastern Europe: Trade and Investment Issues. In: Weiqing Song (szerk.): China's relations with Central and Eastern Europe: from „old comrades” to new partners. London, Routledge, 48-65. o.

Szunomár, Ágnes - Völgyi, Katalin - Matura, Tamás [2014]: Chinese investments and financial engagement in Visegrad countries: myth or reality? Institute of World Economics, Working Paper, 208. Budapest.

Szunomár Ágnes [2013]: Kínai befektetések Magyarországon. Ábránd vagy sikertörténet? Geopolitika a 21. században, február, 183-191. o.

The Economist Intelligence Unit [2015]: Chinese investments in developed markets: An opportunity for both sides? A report by The Economist Intelligence Unit.

UNCTAD [2018]: World Investment Report. Investment and New Industrial Policies. UNCTAD, Geneva.

van Hoorn, A. - Maseland, R. [2016]: How institutions matter for international business: Institutional distance effects vs. institutional profile effects. Journal of International Business Studies, Vol. 47. No. 3., 374-381. o.

Verbeke, A. - Kano, L. [2015]: The New Internalization Theory and Multinational Enterprises from Emerging Economies: A Business History Perspective. Business History Review, Vol. 89., No. 3., 415-445. o. 
Hol volt, hol nem volt... Kínai tőkebefektetések Magyarországon...

Xie, Q. [2017]: Firm age, marketization, and entry mode choices of emerging economy firms: Evidence from listed firms in China. Journal of World Business, Vol. 52., No. 3., 372-385. o.

Zhu, J. - Tham, E. [2018]: Exclusive: China's CEFC was scrambling for loans as authorities swooped. Reuters. Letölthető: https://www.reuters.com/article/us-china-cefc-loans/exclusive-chinas-cefcwas-scrambling-for-loans-as-authorities-swooped-idUSKCN1GO0DE

\section{MEGRENDELŐLAP}

Megrendelem a KOPINT Konjunktúra Kutatási Alapítvány 2019. évi KÜLGAZDASÁG c. folyóiratát .............. példányban, ára: $10800 \mathrm{Ft} / \mathrm{e} v$, $5400 \mathrm{Ft}$ /félév.

Megrendelő neve:

Megrendelő címe:

Megrendelő postafiókcíme:

Megrendelő e-mail címe:

Telefon:

Telefax:

Ügyintéző neve, telefonszáma:

Fizetési mód: Csekken: $\square$ Átutalással: $\square$

(Számlaszámunk: 11100104-19659963-10000001)

Kérjük, hogy a 2019-es megrendelésüket az alábbi elérhetőségeken jelezzék számunkra.

\section{Külgazdaság Szerkesztősége}

1112 Budapest, Budaörsi út 45. • 1518 Budapest, Pf.: 71 web: www.kulgazdasag.eu • e-mail: kulgazdasag@kopint-tarki.hu

Tel.: 309-2695 • Fax: 309-2647 


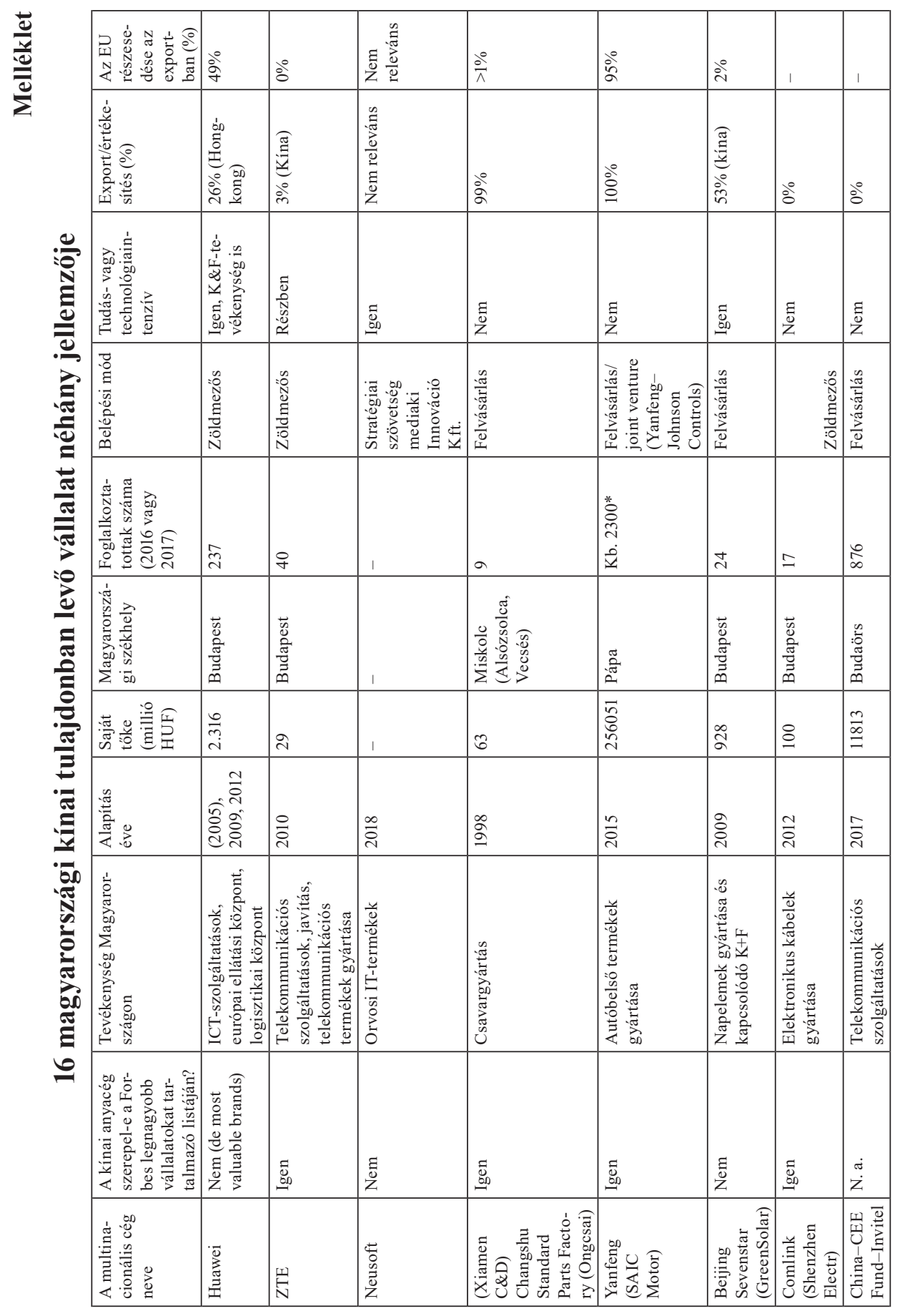


Hol volt, hol nem volt... Kínai tőkebefektetések Magyarországon...

\begin{tabular}{|c|c|c|c|c|c|c|c|c|}
\hline 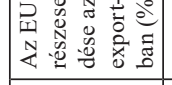 & @̊̀ & ڤूे & । & 1 & 1 & ذి & ז் & $\ddot{z}$ \\
\hline 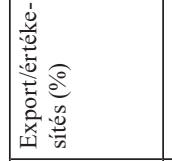 & छे & 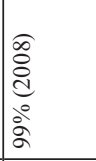 & 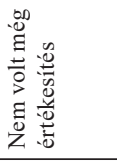 & 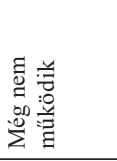 & 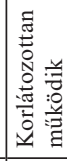 & $\begin{array}{l} \\
\vdots \\
\vdots \\
\infty \\
\infty\end{array}$ & $\ddot{z}$ & $\ddot{z}$ \\
\hline 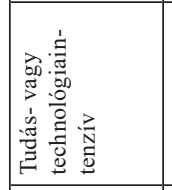 & 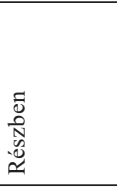 & ¿ू & ¿ू & ¿ू & 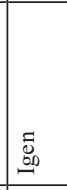 & 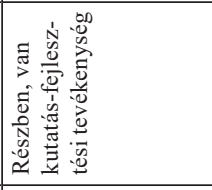 & 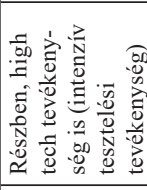 & है \\
\hline 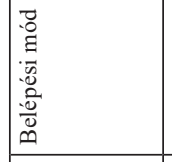 & 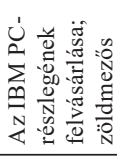 & 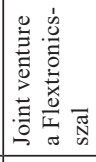 & 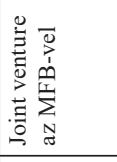 & 产 & 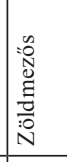 & 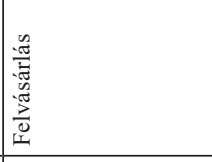 & 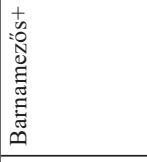 & 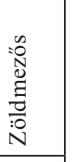 \\
\hline 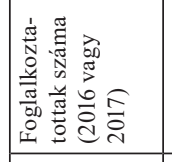 & 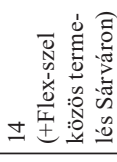 & & ז் & 0 & $\mathrm{~N}$ & $\begin{array}{l}\stackrel{5}{5} \\
\text { a }\end{array}$ & r & ț \\
\hline 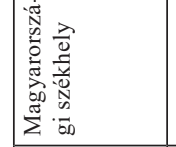 & 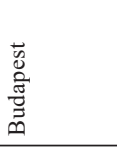 & 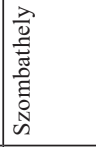 & 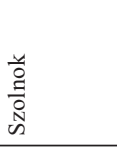 & 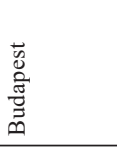 & 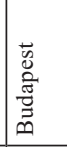 & 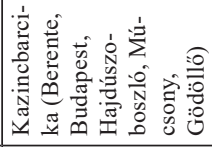 & 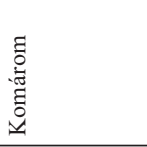 & 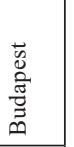 \\
\hline 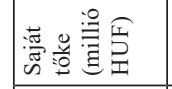 & $\mathrm{m}$ & ז் & ¿্ & $\mathrm{m}$ & $\widehat{\top}$ & $\stackrel{m}{\stackrel{3}{2}}$ & 茫 & $\begin{array}{l}0 \\
\text { : } \\
\end{array}$ \\
\hline 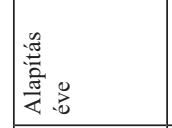 & 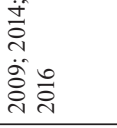 & 营 & స̃ & 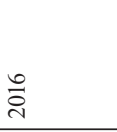 & $\stackrel{n}{n}$ & $\bar{\Xi}$ & ثે & ठั \\
\hline 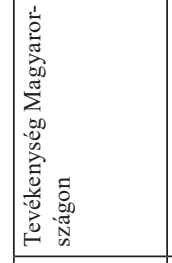 & 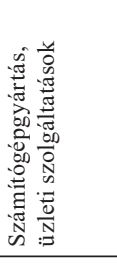 & 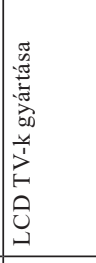 & 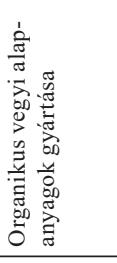 & 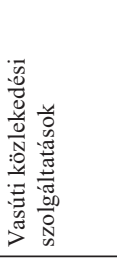 & 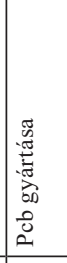 & 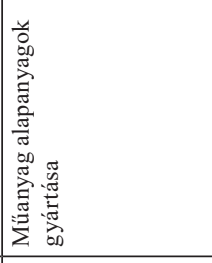 & 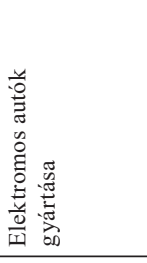 & 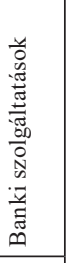 \\
\hline 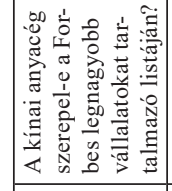 & 产 & 总 & : & 总 & 总 & 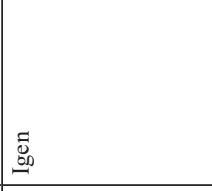 & 总 & 总 \\
\hline 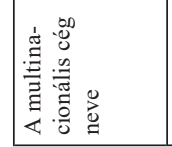 & 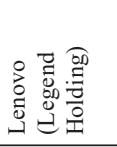 & 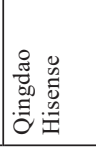 & 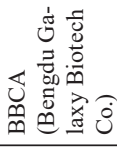 & 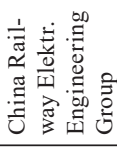 & 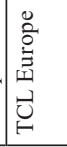 & 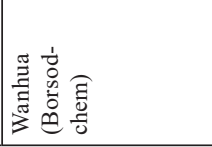 & خ્ટે & 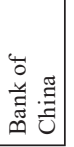 \\
\hline
\end{tabular}

